\title{
Japan's Greater East Asia Co-Prosperity Sphere: Target to Setting up an Economic Zone for the Collective Development of Asian Nations
}

\author{
Ali MS ${ }^{1,2^{*}}$, James $\mathbf{M}^{1}$ \\ ${ }^{I}$ School of Humanities and Sociology, Nottingham Trent University, Nottingham, UK \\ ${ }^{2}$ National University, Bangladesh
}

\begin{abstract}
*Corresponding Author: Ali MS, School of Humanities and Sociology, Nottingham Trent University, Nottingham, UK \& National University, Bangladesh. Email: md.national.u@ gmail.com
\end{abstract}

\begin{abstract}
After the fall of Malaya, Singapore and Burma, a new political development took place in East Asia, bringing together the Japanese military leaders and the Indian leaders in the region. This growth saw the birth of the Indian National Army (INA), which collaborated with the Japanese military government to free India from colonial rule. In 1944, the Imperial Japanese Army and the INA launched a joint campaign in Northeast India. The aim of this joint operation against British-India during the Second World War was to safeguard Japan's "Greater East Asia Co-Prosperity Sphere," particularly Burma on the one hand, and to pave the way for the INA to penetrate India's plains to stir anti-British uprisings for the country's liberation. There was an immediate likelihood of incorporating Imphal and Kohima as the western border of the CoProsperity Sphere had the Japanese captured the Imphal and Kohima battles. Some of the toughest land battles of the Second World War at Imphal and Kohima were fought by British troops. Following months of heavy battles, the British 14th Army defeated the Japanese 15th Army and Bose's INA at Imphal and Kohima.
\end{abstract}

Keywords: Japanese, British, battle, Asian nations, development

\section{INTRODUCTION}

In the 1930s, Japan issued a policy known as the Greater East Asia Co-Prosperity Sphere with the idea of creating an economic zone in which all Asian nations could develop together [1-4]. For the first time in August 1940, Japanese Foreign Minister Matsuoka Yosuke officially used the term "Greater East Asia Co-Prosperity Sphere" [5]. This policy's main objective was to foster East Asia's co-prosperity by ending the long-lasting Western imperialism in Asia and developing Asia for the Asians. The Greater East Asia Co-Prosperity Sphere has generally been viewed in the West as an example of aggressive Japanese imperialism aimed at China and South East Asia [6-12]. But the Japan's Greater East Asia Co-Prosperity Sphere (JGEACS) could not be fully understood in the words of former Japanese Prime Minister Fumimaro Konoe, who planned the Sphere in 1940, unless one could see the unfairly structured political and economic world- A history of the division of the world into "Haves nations and Have-not nations" as the root causes of world conflict. Konoe argued that the introduction of the policy by Japan was also largely attributed to her desire to put an end to such discrimination. But JGEACS was nothing but an act of Japanese imperialism (Yagami) to Cordell Hull [8]

The JGEACS controversy is endless, but the idea definitely had a huge impact on Japan's wartime strategy. It became the country's national objective and by mid-1941 the idea of JGEACS was regarded as a pillar of the hidden discussions of Japanese leadership policies. Major decisions were taken to promote the sphere of co-prosperity and the public quickly accepted it as the national goal of their country. The JGEACS idea became an exciting vision particularly for the young and welleducated Japanese, and it remained popular even after the Second World War and inspired neonationalist ideologues like Ishihara Shintaro and Kobayashi Yoshinori [13]. There are many reports available related on the subject matter but not completely well done. So, this study tried to focus concretely on the Imphal and Kohima's Japanese campaign and victory in 1944 with relation to Japanese army's relationship with the Indian National Army. 
Japan's Greater East Asia Co-Prosperity Sphere: Target to Setting up an Economic Zone for the Collective Development of Asian Nations

\section{Methodology}

This paper is focused on some of the popular war literature and books, journals related to the study area. Archival documents and war literature focused on oral memory were reviewed in order to integrate the opinions of the military witnesses.

\section{RESULTS AND DISCUSSION}

As soon as the Japanese invaded Burma in 1942, their Southern Army ordered the 15th Army to devise a plan to carry out an Assam code invasion dubbed "Operation No. 21." Imphal, Kohima, Dimapur, the Chin Hills, Silchar, Golaghat, Ledo, and Tinsukia were the targets under this project. However, due to several physical challenges cited in particular by the commander of the 18th Division of Japan, Lt. Gen. Mutaguchi, the proposed "Project No. 21" had to be abandoned. But in the following years, after the reorganization of the Northern Burma Defense into the Burma Area Army (BAA) with Lt. Gen. Masakazu Kawabe as its commander, the draft plan of Operation No.21 led to the Imphal operation. The 15th army served under the BAA with four divisions under its command (JM-134, 2011, 13-15) (the 18th, 33rd, 56th and 31st). Burma's Japanese army understood the importance of an Imphal military campaign. When he was commander of the 18th Division of Japan, Lt. Gen. Mutaguchi was strongly opposed to the Imphal-Kohima campaign. But he became an ardent advocate of "Operation No.21," dubbed "Operation U-Go or U," after taking over the command of the Japanese 15th Army in Burma [14-17].

General Tojo, Japan's prime minister had long considered the possibility of a military attack in British India. He provided the go-ahead for the U-Go, an assault on Imphal, on 9 January 1944 [17]. In addition to the successful penetration of the column of Orde Wingate deep behind the Japanese line in 1943, an act that Lt. Gen. Mutaguchi took as a challenge and a threat to the Japanese base in Burma, several other factors also required the Imphal-Kohima campaign. One of these was the imminent danger of the Allied offensive in Burma, prompting the Japanese 15th Army to launch the offensive first [18]. The Japanese High Command had decided that if they were to hold the country against the anticipated Allied offensive, they would have to go to Assam and capture Imphal, the base from which any major British offensive would have to be launched. The 31st Division assigned to Kohima under Lt. Gen. Kotuku Sato was to stop any British reinforcements sent from India, while the 15th and 33rd Divisions carried out a north and south pincer movement on Imphal. The Japanese army was to hold the mountain passes from Kohima and from there west of Imphal and the Manipur River to the Falam and Haka [19] after the occupation of Imphal. The deteriorating situation for Japan in the Pacific region was also a factor in India's launch of the offensive [16]. The reversals in the Pacific Ocean pushed the Japanese army to take one offensive action after another as it became increasingly necessary to recover the initiative somewhere. The Imphal-Kohima drive was seen as one of those efforts to boost the morale of the Japanese government and the people back home. Subhas Chandra Bose, the anti-British nationalist, also inspired the Japanese offensive in Burma. Bose's personality intrigued Kawabe and the latter persuaded the Indian nationalist leader in the 1943 Great East Asian War [20] to launch a major operation against India.

The Imphal-Kohima offensive was assigned to the 15th army of Lt. Gen. Mutaguchi. Imphal, Kohima and Dimapur were the three British strategic positions in northeastern India in the General's assessment. In Dimapur, there were enough stores for several months to support the Japanese army. If the Japanese were able to capture Kohima, Imphal would be cut off by land from the rest of India. Mutaguchi thought it was bound to be a devastating and a terminal blow for the British to capture the massive depot at Dimapur. Not only would it destroy their ability to defend Imphal, it would also affect Stilwell's supply and the chances of an Allied offensive in Burma. Mutaguchi assessed above all that if Dimapur were seized, Bose and the INA would be able to pour into Bengal and start the long-awaited anti-British revolt [21]. The Japanese generals, however, failed to effectively implement their war plans with concerted efforts, particularly in Kohima.

Lt. Gen. Kotuku Sato and Lt. Gen. Kawabe, chief of the BAA, did not see the feasibility of taking Dimapur when the Japanese troops at Kohima were fighting the heavily armed and well-reinforced British 33 Corps in hungry conditionGeneral Sato reported that since the operation began the 15th Army had failed to send him supplies and ammunition [21]. Thus Lt. Gen. Kawabe stopped the enemy's invasion of Dimapur by Sato's 31st Division [20]. Indeed, by giving up Dimapur, the 
Japanese had missed the best chance to win the battle between Imphal and Kohima. Lt. Gen. Kawabe and General Sato, however, applied their common sense and could save the lives of thousands of soldiers who had already been trapped in critical situations in Kohima due to lack of rations, ammunition and medical care. On the other side, Maj. Gen. Shahnawaz Khan said that because of sheer bad luck, the INA and the Japanese failed to take Imphal. He said they almost captured it once and even the British tried to retreat to Dimapur several times, but the INA and the Japanese tried to block the road between Imphal and Kohima. If the road was left open, the British forces were likely to withdraw from Imphal, but the intention of the INA and the Japanese was to seize all British forces and war materials at Imphal. So, with all the retreat roads cut off, British forces were forced to fight against the wall with their backs [22]. The blocking of the Kohima-Imphal road was thus seen by the INA military top brass as a tactical error. After the capture of Kohima, the British forces at Imphal finally defeated the Japanese and the INA with strong air support and reinforcement.

From the above it can usually be understood that the main focus of the 1944 Japanese offensive was not beyond Imphal and Kohima. For example, the two top Japanese army leaders in the region, Terauchi, the commander-in-chief of the Japanese Imperial Forces in Southeast Asia and Kawabe, the commander of the Burma Area Army, did not want to invade India because they did not feel any interest or receive any encouragement from the prominent leaders of the Indian people. Pandit Jawaharlal Nehru and others, on the other hand, had openly declared their contempt for the Japanese and their hostile China policy. Therefore, the Japanese were not interested in anything else they could have invaded India immediately after their victory in 1942 in Burma [23].

Japan found an ally in the Indian National Army and the Indian Provisional Government, organized by Subhas Chandra Bose, in its drive to Southeast Asia during World War II. From the Japanese point of view, the resulting cooperation was an attempt to use the Indian National Army and Free Provisional Government for the purposes of the campaign in Burma and the Greater East Asia CoProsperity Sphere, and from the Indian National Army's point of view a search for a powerful ally in the drive to liberate India from Great Britain's common foe.

On November 24, 1943, in Free India Radio from Saigon, Bose declared that "the INA, in close collaboration with the East Asian Indians and with the aid of Japan's invincible force, will soon embark on its historic march to India for the liberation of its million" [13]. Military disputes emerged when Bose originally agreed to put the INA under Japanese command but later objected to it at the time of the Imphal campaign [12]. Bose addressed the issues related to the INA's active role in the Indian war with the Japanese Southern Expeditionary Forces ' Field Marshall Terauchi C-in-C. The Field Marshall had a low opinion about the INA's efficiency and considered the soldiers after their defeat in Malaya to be "demoralized." The INA soldiers were, in his opinion, trained differently and not conditioned like the Japanese soldiers. They were also used to good British rations and it would be hard for them to resist the temptation to defect again to the other side. Nevertheless, Bose made it clear to Terauchi that there was no need for any liberation of India by the Japanese army and that it was necessary to allow the Indians to make the maximum sacrifice. Therefore, it was agreed between the two leaders to send an INA regiment to participate in the Imphal campaign and the rest to be sent up later on the basis of that regiment's satisfactory performance [24]. The size of the 15th army in Japan that fought at Imphal and Kohima was 84,280 and the reinforcement of the INA, 7000 and 4000 [19].

It should be noted that in the Imphal-Kohima campaign, unlike the British who had made the best use of the native sepoys to fight their wars, the Japanese failed to make full use of the INA. Way back in 1942, the Japanese did not rely on Captain Mohan Singh who tried to persuade the Japanese for a war in India in the later part of 1942 or early 1943 [23]. Bose expressed his public confidence in the sincerity of Japanese assistance, but vowed privately not to allow the Japanese to replace the British in India. The relationship between Japan and INA was an awkward one that lasted primarily because the two had a common enemy [12]. Even Field Marshall Terauchi had no confidence in the INA's fighting effectiveness. The INA was made to rely entirely on the Japanese army and did not have its own air cover and artillery. The army didn't even have mortars and the machine guns were only small in size and without spare parts. There was a lack of essential means of communication as well as transport and medical facilities. All of these influenced the INA's fighting capability [25].

Given the complexities of the Japanese-INA relationship during the Imphal-Kohima war, the former had in some ways always done their best for the latter. Lt. Gen. Kawabe claimed in his memoirs that it 
was wrong to condemn the Tojo government on the grounds that the Imphal operation was carried out under Bose's coercion. He added that Bose could not be held directly responsible for the operation, although Bose's attitude towards the Imphal operation had greatly influenced the decision to order the Japanese force to fight to death by the top leadership. In that, even by sacrificing thousands of soldiers to secure Indo-Japanese friendship and cooperation [26], Japan had sought to fulfill its foreign duty.

In 1942, there were opinions that "India should be included in Greater East Asia, which would then be more self-sufficient and complete and powerful than any other economic bloc to be formed after the restoration of peace" [12]. From this perspective, the objective of the Japanese 15th Army campaign in 1944 can also be understood. It was said earlier that General Tojo, Japan's Prime Minister, was committed to India's political cause, which he announced unequivocally in the Japanese Diet. But BAA leader Kawabe said in his autobiography that the Imphal operation was conceived on strategic grounds alone. The Imphal campaign's sole aim was therefore to neutralize the British desire to launch counter-offensive to recapture Burma. This plan was not designed as part of Japan's Indian policy [26]. Maybe Imphal was regarded by the Japanese army as part of the Co-Prosperity Sphere because Bose was asked to air a radio broadcast on the Emperor's birthday just before the attack began, offering Imphal as a present [27].

Retrospectively, on 5 November 1943, Bose attended the Great East Asia Conference in Tokyo with the Indian delegates as observers. Bose took the seat of the observer because, in his opinion, India did not include the Great East Asia Co-Prosperity Sphere. There was also no direct reference to India in the Great East Asia Declaration made by General Tojo. Bose expressed his happiness as an observer at the conference, and Tojo again pledged Japan's firm support for the struggle for Indian independence. He also announced the ongoing planning for the transition of the Andaman and Nicobar Islands to independent India's provisional government [26]. This was seen as an empty gesture, however, as the islands were penal colonies in the Bay of Bengal and were under Japanese Navy occupation [16]. Bose hoped JGEACS would pave the way for a Pan-Asian Federation, which would eventually lead to a world federation [12]. Yet Bose also saw some problems as, as resources decreased, demand for more Japanese support collapsed. This prompted Bose and his followers to believe that Japan would replace India's Britain [12]. In fact, the JGEACS geographical limit was not accepted and there were many different views on this. Since 1941, there have been speculations that the "Greater Domain," or "sphere of influence," would sweep through Asia and include India, Australia, and New Zealand. The western boundary of the sphere, according to the Japanese military policy, was not outside Burma. But even as late as 1942, how much of Burma was in dispute within the army to be embraced. India was part of the "vision" of the sphere of influence, and Imphal was the western limit of strategic operations within the Indian border [12].

For more than two months, the Japanese 31st Division fought in Kohima and had close association with the Naga people of the present district of Phek and Kohima. They had stressed the importance of the Mongolians ' racial affinity, the basis of the JGEACS, during their entry into the Naga villages. The people were told of their "professed mission to protect the Mongolian race from white British rule" [28]. They exhorted the people in some places about the similarities they shared with the Nagas and, on the other hand, the differences between the Nagas and the British [3,5,13]. Similarly, the Japanese addressed the villagers as their brothers and sisters in another village on the ground they belonged to the same group of bodied little men. The villagers were also reminded of the well-built British and, thus, not their relatives. The Naga villagers were informed of the importance of helping each other as brothers [3,5,13 ]. Some of the things Japanese soldiers emphasized in every Naga village they entered were similarities in race, culture and food habits. Three informal schools were established in the Naga Hills district in the middle of the war by the Japanese army and the children [13] were given their language and national anthem. A colonial record also shows that during the war, a Japanese Nishi Kikan, who styled himself as the "Nippon Government and Naga Commissioner," had arrived in the Ukhrul area (Manipur). He had urged the village's head that the Japanese and the Indians were the same in all respects. He said the Nippon rule was much stricter than the British rule (ASA, No.140 file). Instances of indoctrination practices in accordance with the JGEACS principles were undertaken by the Japanese military intelligence service in 1944 to gain the natives ' loyalty and approval. 
Japan's Greater East Asia Co-Prosperity Sphere: Target to Setting up an Economic Zone for the Collective Development of Asian Nations

\section{CONClusion}

It can be concluded from the above discussion that Imphal, Kohima or India as a whole, in 1944, was not entirely outside the sphere of influence of the Greater East Asia Co-Prosperity Sphere. The war between Imphal and Kohima was a decisive campaign that led to the destruction of the Japanese and the Indian National Army. The Imphal-Kohima battle also led to the destruction of the JGEACS western border that the Japanese tried to defend by launching the "U-Go" operation. In Imphal and Kohima, the British 14th Army won a clear tactical victory. The British victory's success was because the Japanese did not appreciate Dimapur's importance. The British army had the benefit of logistical support; air and rail allowed them to deliver reinforcements to the battlefields. The Japanese suffered from this because their transport and communication lines had been misunderstood. The 15th Army never received any supply and strengthening from the 31st Division. The British also had a distinct advantage over the Japanese in terms of combat equipment. Lt. Gen. Mutaguchi acknowledged that the Japanese failure was due in part to the command structure of the army and in part to the disagreements between him and the commander of the Army Group, Lt. Gen. Kawabe, as to how the operation was to be carried out. Kawabe's cancelation of Mutaguchi's order to make a dash for Dimapur to Lt. Gen. Sato changed the entire prospect of the Japanese winning the war. Mutaguchi argued that "the British won the war because of the commanders ' ability to select and follow a successful course of action with determined intent". Imphal-Kohima's battle ended the myth of Japanese invincibility and the INA march on Delhi came to an end with it.

\section{REFERENCES}

[1] Swan, W. L. (1996). Japan's Intentions for Its Greater East Asia Co-Prosperity Sphere as Indicated in Its Policy Plans for Thailand. Journal of Southeast Asian Studies, 27(1), 139-149.

[2] Smith, W. D. (2000). Beyond the bridge on the River Kwai: Labor mobilization in the greater East Asia co-prosperity sphere. International Labor and Working-Class History, 58, 219-238.

[3] Mimura, J. (2011). Japan's New Order and Greater East Asia Co-Prosperity Sphere: Planning for Empire. The Asia-Pacific Journal: Japan Focus, 9(49).

[4] Furuoka, F. (2005). Japan and the flying geese pattern of East Asian integration. Journal of Contemporary Eastern Asia, 4(1), 1-7.

[5] Cook, H. T., \& Cook, T. F. (1991). Japan at War: An Oral History (New York, 1992); Henry Rousso. The Vichy Syndrome: History and Memory in France since 1944, 771-816.

[6] Barnes, G. L. (1993). China, Korea and Japan: the rise of civilization in East Asia. London: Thames \& Hudson.

[7] Fisher, C. A. (1950). The Expansion of Japan: A Study in Oriental Geopolitics: Part II. The Greater East Asia Co-Prosperity Sphere. The Geographical Journal, 115(4/6), 179-193.

[8] Keong-il, K. (2005). Nationalism and Colonialism in Japan's "Greater East Asia Co-Prosperity Sphere" in World War II. The Review of Korean Studies, 8(2), 65-89.

[9] Grajdanzev, A. J. (1943). Japan's Co-Prosperity Sphere. Pacific Affairs, 16(3), 311-328.

[10] Milner, A., \& Johnson, D. (2001). The idea of Asia.

[11] Choi, J. (2010). Of the East Asian cultural sphere: Theorizing cultural regionalization. China Review, 109136.

[12] Lebra-Chapman, J. (1975). Japan's Greater East Asia co-prosperity sphere in World War II: selected readings and documents. Oxford University Press.

[13] Duus, P. (2008). The Greater East Asian Co-Prosperity Sphere: Dream and Reality. Journal of Northeast Asian History, 5(1), 143-154.

[14] Terakura, S. Burma Operations Record. Japanese Monographs, (57), 234.

[15] Dupuy, T. N. (1963). The Military History of World War II.: Allied Victories in China and Burma. Asiatic Land Battles. Franklin Watts.

[16] Allen, L. (1984). Burma: the longest war 1941-1945. London: Phoenix Press.

[17] McLynn, F. (2011). The Burma campaign: disaster into triumph, 1942-45. Yale University Press.

[18] Evans, G. C., \& Brett-James, A. (1962). Imphal: a flower on lofty heights. Macmillan

[19] Kirby, S. W. (1961). The war against Japan. Vol. 3, The decisive battles. HM Stationery Office.

[20] Bond, B., \& Tachikawa, K. (Eds.). (2004). British and Japanese Military Leadership in the Far Eastern War, 1941-45. Routledge. 
Japan's Greater East Asia Co-Prosperity Sphere: Target to Setting up an Economic Zone for the Collective Development of Asian Nations

[21] Swinson, A. (1967). The Battle of Kohima. Stein and Day.

[22] Khan, S. N. (1946). My Memories of INA and its Netaji. Rajkamal Publications.

[23] Chatterji, A. C. (1947). India's struggle for freedom. Chuckervertty, Chatterjee \& Company.

[24] Ghosh, K. K. (1969). The Indian National Army: second front of the Indian independence movement. Meenakshi Prakashan.

[25] Chand, T. (1972). History of the Freedom Movement in India (Vol. 3). Publications Division, Ministry of Information and Broadcasting.

[26] Sareen, T. R. (2004). Indian National Army: A Documentary Study. Gyan.

[27] Toland, J. (2003). The Rising Sun: The Decline and Fall of the Japanese Empire, 1936-1945. Modern Library War.

[28] Krocha, V. R., \& Dukru, R. R. (2013). Chakhesang: A Window to Phek District. Kohima: Chakhesang Student Union

Citation: Ali MS, James M. “Japan's Greater East Asia Co-Prosperity Sphere: Target to Setting up an Economic Zone for the Collective Development of Asian Nations”. International Journal of History and Cultural Studies (IJHCS). vol 6, no. 1, 2020, pp. 1-6 doi: DOI: http://dx.doi.org/10.20431/2454-7654.0601001.

Copyright: (c) 2020 Authors. This is an open-access article distributed under the terms of the Creative Commons Attribution License, which permits unrestricted use, distribution, and reproduction in any medium, provided the original author and source are credited. 